\title{
FAKTOR-FAKTOR YANG MEMPENGARUHI PENOLAKAN PEMAKAIAN PUPUK ORGANIK
}

\author{
Purwoko \\ Zunan Setiawan \\ Universitas Ahmad Dahlan \\ purwokopurwo@yahoo.co.id
}

\begin{abstract}
ABSTRAK
The purpose of this study was to test the factors influence of man nature orientation (MNO), experience, attitude, price, and informations that affect resistance to adoption organic fertilizer. Man nature orientation has a significant negative influence on the attitudes. Experience has a negative significant influence on the attitudes. Informations has a negative significant effect on resistance to adoption organic fertilizer. Attitude has a positive significant influence on the interest resistance to adoption organic fertilizer Price has a positive significant effect on resistance to adoption organic fertilizer. Attitude has a positive significant influence on the interest resistance to adoption organic fertilizer. The results of this study can contribute theoretically that the model of resistance to adoption organic fertilizer by using the frame of the theory of planned behavior plus variable mno and experience can reinforce the findings of previous research on resistance to adoption, so that research results can be used to guide examines the resistance to adoption in other settings.
\end{abstract}

Keywords: man nature orientation, informations, price, experience, interest, and resistance to adoption.

\section{PENDAHULUAN}

“Go Organic 2010” sebagai salah satu kebijakan dalam pembangunan pertanian yang pernah diluncurkan Pemerintah Indonesia. Dalam komitmen ini dicanangkan bahwa pada tahun 2010 Indonesia akan menjadi produsen produk pertanian organik terbesar di dunia (Daniel, 2011), tetapi sampai saat ini program “Go Organic 2010” belum bisa tercapai.

Fenomena yang terjadi di lapangan justru sebaliknya banyak petani yang menolak untuk memakai pupuk organik bersubsidi, meskipun pupuk organik ini diberikan dengan harga yang disubsidi oleh pemerintah (Ilham, 2013).
Mencermati fenomena tentang adanya penolakan untuk memakai pupuk organik bersubsidi, maka perlu dilakukan penelitian untuk mengetahui perilaku menolak pupuk organik tersebut. Kajian perilaku konsumen bisa diterapkan dalam menganalisis perilaku penolakan pemakaian pupuk organik ini.

Peneliti akan menggunakan dasar pemikiran dari Modified Theory of Planned Behavior atau teori perilaku terencana modifikasi dari Ajzen (2005), karena model penelitian ini dianggap tepat untuk memprediksi perilaku penolakan suatu produk. Modified Theory of Planned Behavior menunjukkan bahwa perilaku seseorang akan dipengaruhi oleh minat; minat 
berperilaku akan dipengaruhi oleh sikap, norma subyektif dan persepsi kontrol keperilakuan; sikap dipengaruhi oleh faktor-faktor latar belakang individu.

Hasil pengamatan yang dilakukan peneliti dalam studi eksploratori awal (2012) ada beberapa hal yang menyebabkan perilaku pemakaian pupuk organik bersubsidi oleh petani tidak berjalan seperti yang diharapkan yaitu : (1) petani tidak mau memakai lagi pupuk organik bersubsidi karena petani pernah gagal panen pada saat memakai pupuk bersubsidi tersebut, (2) pupuk organik bersubsidi ini dianggap petani mempunyai kualitas yang jelek, kandungan hara yang ada dalam pupuk organik bersubsidi ini sangat tidak sesuai dengan kebutuhan tanah yang ada di wilayah pertaniannya, (3) kurangnya sosialisasi dan uji coba penggunaan pupuk organik bersubsidi menyebabkan petani kurang percaya pada pupuk organik bersubsidi, (4) petani mempersepsikan risiko yang tinggi jika memakai pupuk organik bersubsidi.

Penelitian ini akan menguji sebuah model baru yang dibentuk untuk menjelaskan hubungan sejumlah faktor dalam perilaku penolakan pemakaian pupuk organik bersubsidi, dengan kerangka berpikir dari Modified Theory of Planned Behavior atau teori perilaku terencana modifikasi dari Ajzen (2005) dengan melibatkan faktor latar belakang nilai orientasi manusiaalam dan pengalaman. Dari latar belakang yang mempengaruhi sikap di teori perilaku terencana modifikasi, dipilihlah variabel nilai orientasi manusia-alam dan pengalaman. Pemilihan variabel dilakukan melalui in dept interview dan Focus Group Discusion.

Dengan demikian permasalahan yang akan dibahas pada penelitian ini meliputi: (1) Apakah variabel nilai kepedulian terhadap alam berpengaruh pada sikap menolak memakai pupuk organik?; (2) Apakah variabel pengalaman berpengaruh pada sikap menolak memakai pupuk organik?; (3) Apakah sikap menolak memakai pupuk organik berpengaruh terhadap minat menolak memakai pupuk organik?; (4) Apakah informasi tentang pupuk organik berpengaruh terhadap minat menolak memakai pupuk organik?; (5) Apakah harga pupuk organik berpengaruh terhadap minat menolak memakai pupuk organik?; (6) Apakah minat menolak memakai pupuk organik berpengaruh pada perilaku penolakan pemakaian pupuk organik?; (7) Apakah harga pupuk organik berpengaruh pada perilaku penolakan pemakaian pupuk organik?

\section{REVIEW LITERATUR DAN HIPOTESIS}

\section{Perilaku Konsumen}

Pengertian perilaku konsumen menurut Shiffman dan Kanuk (2012) adalah studi mengenai individu, kelompok, organisasi dan proses yang mereka gunakan untuk: memilih, memelihara, menggunakan, membuang produk, jasa, pengalaman dan ide untuk memuaskan kebutuhan dan mempelajari proses tersebut pada konsumen dan masyarakat. Pengertian perilaku konsumen menurut Engel et al. (1995) adalah: tindakan yang langsung terlibat dalam mendapatkan, mengkonsumsi, dan menghabiskan produk dan jasa, termasuk proses yang mendahului dan menyusul dari tindakan ini. Assael (1998), mengartikan perilaku konsumen sebagai aktivitas yang dilakukan dalam rangka memperoleh, mengkonsumsi, dan mengatur barang dan jasa termasuk proses pengambilan keputusan yang dilakukan sebelum dan sesudah aktivitas-aktivitas tersebut.

\section{Modified Theory of Planned Behavior}

Teori yang menjadi dasar perilaku konsumen dikemukakan oleh Ajzen dan Fishbein (1975). Ajzen dan Fishbein (1975) mengajukan The Theory of Reasoned Action (TRA). TRA menunjukkan bahwa perilaku seseorang akan dipengaruhi oleh minat, dan minat akan 
dipengaruhi oleh sikap. Theory of Planned Behavior (TPB) merupakan pengembangan lebih lanjut dari Theory of Reasoned Action (TRA), Ajzen (1985) menambahkan konstruk yang belum ada dalam Theory of Reasoned Action yaitu persepsi kontrol keperilakuan (perceived behavior control).

Konstruk ini ditambahkan dalam upaya memahami keterbatasan yang dimiliki individu dalam rangka melakukan perilaku tertentu, dengan kata lain dilakukan atau tidak dilakukannya suatu perilaku tidak hanya ditentukan oleh sikap dan norma subyektif semata, tetapi juga persepsi individu terhadap kontrol yang dapat dilakukannya yang bersumber pada keyakinan terhadap kontrol tersebut (control beliefs). Ajzen (2005) melakukan modifikasi pada teori perilaku terencana dengan menambakan faktor latar belakang individu yang dinamakan Modified Theory of Planned Behavior atau teori perilaku terencana modifikasi, seperti personal, sosial dan informasi yang mempengaruhi sikap dan perilaku individu. Faktor latar belakang penelitian merupakan bagian yang perlu diteliti lebih lanjut karena masih sedikit penelitian yang mempertimbangkan faktor tersebut dalam menjelaskan teori perilaku terencana.

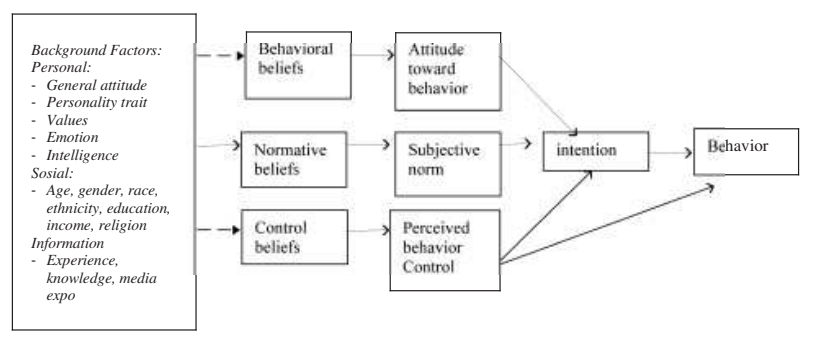

\section{Gambar 1. Modified Theory of Planned Behavior (Ajzen, 2005)}

\section{Pupuk Organik sebagai Produk Inovasi}

Rogers (1995) menyatakan bahwa sebuah produk bisa dikatakan sebagai produk inovasi bagi konsumennya jika :

1. Gagasan baru yaitu suatu olah pikir dalam mengamati suatu fenomena yang sedang terjadi, termasuk dalam bidang pertanian, gagasan baru ini dapat berupa penemuan dari suatu gagasan pemikiran, ide, sistem sampai pada kemungkinan gagasan yang mengkristal.

2. Produk dan jasa yaitu hasil langkah lanjutan dari adanya gagasan baru yang ditindak lanjuti dengan berbagai aktivitas, kajian, penelitian dan percobaan sehingga melahirkan konsep yang lebih konkret dalam bentuk produk dan jasa yang siap dikembangkan dan dimplementasikan termasuk hasil inovasi dibidang pertanian.

3. Upaya perbaikan yaitu usaha sistematis untuk melakukan penyempurnaan dan melakukan perbaikan (improvement) yang terus menerus sehingga inovasi itu dapat dirasakan manfaatnya.

4. Pupuk organik merupakan pupuk yang sebagian atau seluruhnya terdiri dari bahan organik yang berasal dari sisa tanaman dan atau kotoran hewan, yang telah melalui proses, rekayasa, berbentuk padat atau cair yang digunakan untuk mensuplai hara tanaman, memperbaiki sifat fisik, kimia dan biologi tanah. Pupuk organik merupakan bentuk inovasi teknologi baru di bidang pertanian (Balingtan, 2010).

Mengapa pupuk organik dikatakan sebagai produk dengan inovasi baru? Menurut Balai Penelitian Lingkungan Pertanian (Balingtan), karena dalam proses pembuatan pupuk organik selalu ada teknologi baru yang dimasukkan, yaitu antara terkait cara pengolahan pupuk organiknya, bahan baku yang digunakan dalam campuran pembuatan pupuk organik, teknologi bioaktivator yang digunakan untuk memproses pupuk organik.

Rogers (1995) membagi penolakan inovasi ke dalam dua tipe yaitu (1) penolakan aktif yaitu pertimbangan individu untuk menggunakan suatu inovasi termasuk mencoba inovasi tetapi kemudian memutuskan untuk melakukan penolakan inovasi, (2) penolakan 
pasif yang merupakan kelompok individu yang sama sekali tidak mempertimbangkan untuk mencoba menggunakan suatu inovasi.

Marakas dan Hornik (1996) menjelaskan resistance behavior sebagai sebuah respon untuk menentang dengan adanya sistem baru. Resistance to change diilustrasikan sebagai respon yang sifatnya negatif yang terkait dengan dimensi emosional, kognitif dan intensional dari seorang individu.

\section{Kesenjangan Penelitian}

Penelitian tentang perilaku menolak dan sepengetahuan peneliti, belum pernah dilakukan oleh peneliti-peneliti sebelumnya. Penelitipeneliti sebelumnya meneliti tentang perilaku membeli, perilaku memakai, perilaku menunda membeli atau perilaku menunda memakai, sehingga penelitian perilaku menolak mengisi kesenjangan tentang penelitian perilaku dan sepengetahuan peneliti di Indonesia juga belum pernah ada yang meneliti.

Kesenjangan lain dari penelitian ini adalah masih adanya ketidakkonsistenan pengaruh variabel nilai kepedulian terhadap alam (orientasi manusia-alam) dan pengalaman terhadap variabel sikap. Dengan demikian perlu untuk menjustifikasi ulang pengaruh variabel orientasi manusia-alam dan pengalaman pada sikap.

\section{Kerangka Konseptual}

Kerangka konseptual dalam penelitian ini menggunakan kerangka berpikir teori perilaku terencana modifikasi (Ajzen, 2005) dengan melibatkan faktor latar belakang nilai kepedulian terhadap alam (orientasi manusia-alam) dan pengalaman, yang secara langsung mempengaruhi sikap dalam penolakan pemakaian pupuk organik bersubsidi.

Nilai kepedulian terhadap alam berisi nilai-nilai yang mengarah pada hubungan manusia dengan alam sehingga konsumen berupaya mencari informasi-informasi yang berkaitan dengan masalah lingkungan. Hasil penelitian yang dilakukan oleh Chan dan Lau (2000), Christian AK (2011), dan Wijaya (2013) menunjukkan bahwa pandangan seorang individu terhadap alam akan berpengaruh pada sikap dalam pembelian produk-produk organik. Sedangkan Aman et al (2012) dalam penelitianya menyatakan bahwa nilai orientasi manusi-alam tidak secara langsung berpengaruh terhadap sikap. Sehingga masih ada ketidakkonsistenan hasil penelitian mengenai pengaruh nilai orientasi manusia-alam terhadap sikap seseorang.

Sedangkan faktor latar belakang yang berupa pengalaman, menurut hasil penelitian sebelumnya juga menunjukkan hasil yang belum konsisten. Hasil penelitian Park et al., (2007) "Adoption of Mobile Technologies for Chinese Consumers" menyatakan bahwa pengalaman hanyalah merupakan variabel moderating yang tidak memiliki pangaruh secara langsung terhadap sikap seseorang, sedangkan Fiore dan Kim (2007) dan Taylor, Todd (1995) dan Chi dan Yamada (2002) menyatakan bahwa pengalaman merupakan variabel yang secara langsung mempengaruhi sikap.

Perbedaan penelitian ini dengan penelitian-penelitian sebelumnya terletak pada perilaku menolak, yang sepengetahuan peneliti belum pernah diteliti. Penelitian perilaku yang sudah sering diteliti tentang perilaku beli, perilaku pakai, perilaku tunda beli dan perilaku tunda pakai. Penelitian terdahulu obyek penelitiannya adalah green product atau produk hijau atau produk pertanian organik tetapi pada penelitian ini akan meneliti pupuk organik bersubsidi yang merupakan produk yang digunakan untuk memproduksi green product. Kerangka konseptual penelitiannya adalah : 


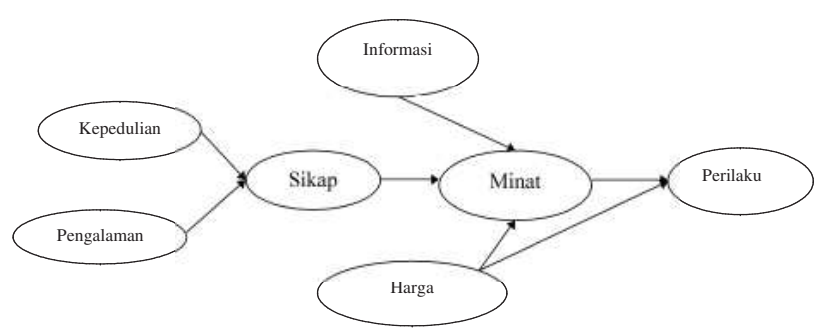

Gambar 2. Kerangka Konseptual

\section{Pengembangan Hipotesis}

Hipotesis 1: Nilai kepedulian terhadap lingkungan berpengaruh negatif terhadap sikap menolak memakai pupuk organik bersubsidi.

Hipotesis 2: Pengalaman memakai pupuk organik bersubsidi berpengaruh negatif terhadap sikap menolak memakai pupuk organik bersubsidi.

Hipotesis 3: Informasi tentang pupuk organik berpengaruh negatif terhadap minat menolak memakai pupuk organik bersubsidi.

Hipotesis 4: Harga pupuk organik berpengaruh positif terhadap minat menolak memakai pupuk organik bersubsidi.

Hipotesis 5: Harga pupuk organik berpengaruh positif terhadap perilaku menolak memakai pupuk organik bersubsidi.

Hipotesis 6: Sikap menolak berpengaruh positif terhadap minat menolak memakai pupuk organik bersubsidi.

Hipotesis 7: Minat menolak berpengaruh positif terhadap perilaku menolak memakai pupuk organik bersubsidi

\section{METODE PENELITIAN}

Studi pendahuluan yang dilakukan menggunakan desain non probability sampling. Alasan yang mendasari adalah karena populasi individu yang menolak pemakaian pupuk organik bersubsidi tidak diketahui secara jelas, sehingga penetapan sampel secara acak tidak bisa dilakukan (Cooper dan Schindler, 2013). Dalam tahap ini digunakan judgmental sampling method dengan kriteria tertentu. Studi pendahuluan menghasilkan temuan-temuan yang memberikan gambaran fenomena dalam penolakan pemakaian pupuk organik bersubsidi.

Setelah melakukan FGD maka diperolah 25 instrumen penelitian dan dialakukan uji validitas dan reliabilitas. Hasil uji validitas menggunakan analisis faktor, ke 25 instrumen tersebut valid karena memiliki $C R \geq 2$ dan $\mathrm{p} £$ 0.05 (Hair, 1998, Cooper and Schindler, 2003), dan instrumen ini dipakai untuk pengolahan data lebih lanjut. Hasil pengujian Construct Reliability sudah menunjukkan hasil yang baik karena semua konstruk laten memiliki nilai CR yang disyaratkan yaitu CR ${ }^{3}$ 0,5 (Hair, 2006 : 777), sehingga data ini dipakai untuk pengolahan data lebih lanjut.

\section{Kelompok Variabel Penelitian: Eksogen dan Endogen}

Variabel eksogen tidak dipengaruhi oleh variabel lainnya tetapi mempengaruhi variabel endogen dalam diagram alur, yang meliputi : nilai kepedulian terhadap alam, pengalaman, informasi dan harga, sedangkan variabel endogen adalah variabel yang dipengaruhi oleh satu atau beberapa variabel yang ada dan meliputi : sikap menolak memakai pupuk organik bersubsidi, minat menolak memakai pupuk organik bersubsidi dan perilaku menolak memakai pupuk organik bersubsidi.

\section{Populasi dan Sampel}

Populasi dalam penelitian ini adalah seluruh petani yang pernah memakai pupuk organik bersubsidi dan selanjutnya menolak memakai pupuk organik bersubsidi lagi di seluruh Indonesia yang memiliki karakteristik sama dengan petani di wilayah Dataran Tinggi Dieng Jawa Tengah. Jumlah sampel yang diambil mengacu pada pendapat Hair et al (1998) yang menyatakan bahwa jumlah minimal sampel agar 
sebuah pengujian data memiliki statistical power yang dapat dipertanggung jawabkan adalah lima kali indikator yang dianalisis. Jumlah parameter/ indikator dalam penelitian ini sejumlah 25. Jadi minimal sampelnya adalah sejumlah 125 orang. Jumlah sampel yang akan digunakan untuk penelitian ini adalah 200 sehingga sudah memenuhi batas minimal statistical power.

\section{Rancangan Analisis Data}

Model yang digunakan untuk menganalisis data dalam penelitian ini adalah Structural Equation Modelling (SEM). Model pengukuran variabel orientasi manusia-alam, pengalaman, sikap, norma subyektif, persepsi harga sebagai persepsi kontrol keperilakuan, niat dan perilaku penolakan pemakaian menggunakan Confirmatory Factor Analysis.

\section{Penilaian Problem dan Identifikasi.}

Identification problem pada prinsipnya adalah problem mengenai ketidakmampuan dari model yang dikembangkan untuk menghasilkan estimasi yang unik. Pengujian terhadap model yang dikembangkan dengan berbagai kriteria Goodness of Fit. Tabel berikut ini mencantumkan indikator yang harus dipenuhi agar model dapat dikatakan baik dan dapat digunakan, sebagai berikut:

Tabel 1. Indikator Goodness of Fit Model

\begin{tabular}{|l|c|}
\hline Indeks Goodness of Fit & Cut off Value \\
\hline Absolute fit measures & \\
\hline $\mathrm{X}^{2}$-Chi square & Kecil \\
\hline $\mathrm{p}$ (signifikansi) & $\geq 0,05$ \\
\hline Root Mean Square Error of Approximation & $\leq 0,08$ \\
\hline Goodness of Fit Index & $\geq 0,90$ \\
\hline Incremental fit measures & $\geq 0,90$ \\
\hline Adjusted Goodness of Fit Index & $\geq 0,95$ \\
\hline Comparative Fit Index & $\geq 0,95$ \\
\hline Tucker Lewis Index & \\
\hline Parsimonious fit measures. & $\leq 2,00$ \\
\hline CMIN/DF &
\end{tabular}

Sumber : Hair (1992), Bentler (1983), Arbukle (1997)

\section{Intepretasi Hasil}

1. Melakukan intepretasi terhadap hasil pengukuran konstrak laten dengan berpedoman pada tingkat signifikansi loading factor atau koefisien lamda (1) yang berpatokan pada nilai CR, dianggap signifikan apabila nilai $\mathrm{CR} \geq 2$.

2. Selanjutnya menguji model lengkap yang berasal dari seluruh konstruk dan indikator yang signifikan untuk mengkaji faktorfaktor yang berpengaruh terhadap penolakan pemakaian pupuk organik bersubsidi dengan mengamati koefisien jalur (regresi terstandar), baik arah, besaran, maupun signifikansi. Penilaian signifikansi berpedoman pada nilai $\mathrm{CR} \geq 2$, pada tingkat signifikansi yang digunakan adalah nilai $\mathrm{p} £ 0,05$.

\section{HASIL PENELITIAN DAN PEMBAHASAN}

\subsection{Uji Data Penelitian}

\section{Analisis Kecocokan Model Dengan CFA}

Confirmatory Factor Analysis (CFA) dilakukan terhadap model pengukuran untuk mengkonfirmasi apakah variabel-variabel penelitian secara bersama-sama cukup kuat mencerminkan sebuah dimensi masing-masing variabel model penelitian. CFA dapat digunakan untuk menguji hipotesis mengenai model.

Setelah melakukan beberapa uji CFA didapat hasil yang tidak signifikan, maka harus dilakukan revisi dengan menghilangkan beberapa variabel dan hasil akhir setelah dilakukan revisi, maka dihasilkan output CFA yang menunjukkan bahwa probalibitas signifikasi model sebesar 0,114 yang berarti bahwa pada model tidak terjadi perbedaan antara matriks kovarian sampel dengan matrik kovarian populasi atau hipotesis nol dapat diterima. Dengan demikian sampel dapat mewakili populasi penelitian. 


\section{Validitas dan Reliabilitas Data Penelitian}

Validitas konstruk dikembangkan dengan menentukan apakah setiap indikator yang diprediksi secara valid mengukur konsep yang diujikan. Indikator dikatakan valid apabila CR $\geq 2$ dan p $£ 0,05$ (Hair, 2006). Dari hasil analisa, semua indikator memiliki $C R \geq 2$ dan $p £ 0,05$.

Hasil pengujian reliabilitas konsistensi internal untuk setiap construct dengan menggunakan pengujian construct reliability. Construct reliability menunjukkan instrumen konsisten, yang ditunjukkan dengan nilai construct reliability $\geq 0,5$ (Hair, 2006 : 777). Hasil pengujian reliabilitas konstruk, menunjukkan bahwa CR semua variabel hasilnya $\geq 0,5$, yaitu antara 0,545 sampai dengan 0,832 yang berrat instrumen pengukuran mempunyai hasil yang konsisten.

\section{Hasil Analisa Deskriptif}

1. Variabel nilai kepedulian terhadap alam sebanyak $68 \%$ responden tingkat kepedulian rendah, sedangkan hanya $17,5 \%$ responden kepedulian agak tinggi, 11,5\% kepedulian tinggi, dan hanya $3 \%$ kepedulian sangat tinggi.

2. Variabel pengalaman menunjukkan ada sebanyak 83,5 \% petani yang memiliki pengalaman hasil panen rendah. Hanya ada $16,5 \%$ petani hasil panen tinggi dengan menggunakan pupuk organik bersubsidi.

3. Variabel sikap menolak memakai pupuk organik bersubsidi, petani yang sikapnya menolak sebanyak $91,5 \%$ dan $8,5 \%$ menerima pupuk organik bersubsidi.

4. Variabel harga menunjukkan ada 53,5\% petani mepersepsikan mahal dan tidak berkualitas, sedangkan ada 46,5 \% petani mempersepsikan murah dan berkualitas.

5. Variabel minat menolak memakai pupuk organik bersubsidi, sebanyak $93,5 \%$ berminat menolak dan hanya ada $6,5 \%$ yang berminat untuk memakai pupuk organik bersubsidi.
6. Variabel perilaku menolak memakai pupuk organik bersubsidi menunjukkan bahwa petani yang menolak mamakai pupuk organik bersubsidi sebanyak $89,5 \%$, dan ada sebanyak $10,5 \%$ mau memakai.

\section{Evaluasi Terhadap Model}

Pengujian model dilakukan dengan Structural Equation Modelling (SEM). Pengujian model SEM digunakan untuk melihat kesesuaian model. Hipotesis kesesuaian yang diajukan sebagai berikut : Hipotesis nol : tidal terdapat perbedaan antara matriks kovarians sampel dan matriks kovarians populasi yang diestimasi. Dengan nilai signifikansi sebesar 0,147 berarti hipotesis nol yang menyatakan tidak terdapat perbedaan antara matriks kovarians sampel dan matriks kovarians populasi yang diestimasi dapat diterima.

Hasil analisis data ini menunjukkan bahwa nilai Indeks Goodness of Fit Model yang dikembangkan untuk menjelaskan perilaku penolakan pemakaian pupuk organik bersubsidi sudah seperti yang diharapkan.

\section{Tabel 2 : Goodness of Fit Model Akhir}

\begin{tabular}{|c|c|c|c|c|}
\hline $\begin{array}{l}\text { Tipe good- } \\
\text { ness of fit } \\
\text { model }\end{array}$ & $\begin{array}{c}\text { Indeks Good- } \\
\text { ness of Fit } \\
\text { Model }\end{array}$ & $\begin{array}{l}\text { Nilai yang direko- } \\
\text { mendasikan }\end{array}$ & Hasil & Keterangan \\
\hline $\begin{array}{l}\text { Absolute fit } \\
\text { measures }\end{array}$ & $\begin{array}{c}\text { Chi-Square } \\
\text { Statistic }\left(\chi^{2} \text { atau }\right. \\
\text { CMIN }) \\
\text { P } \\
\text { GFI } \\
\text { RMSEA }\end{array}$ & $\begin{array}{l}\text { Kecil } \\
\geq 0,05 \\
\geq 0,90 \\
\leq 0,08\end{array}$ & $\begin{array}{r}212,570 \\
0,147 \\
0,914 \\
0,023\end{array}$ & $\begin{array}{c}\text { Baik } \\
\text { Baik } \\
\text { Baik }\end{array}$ \\
\hline $\begin{array}{l}\text { Incremental } \\
\text { fit measures }\end{array}$ & $\begin{array}{c}\text { RMSEA } \\
\text { AGFI } \\
\text { CFI }\end{array}$ & $\begin{array}{l}\geq 0,90 \\
\geq 0,95 \\
>0,95\end{array}$ & $\begin{array}{l}0.887 \\
0.985 \\
0.982\end{array}$ & $\begin{array}{l}\text { Marginal } \\
\text { Baik }\end{array}$ \\
\hline $\begin{array}{l}\text { Parsimonious } \\
\text { fitmeasures }\end{array}$ & $\begin{array}{l}\text { Normed } \chi^{2} \\
\text { (CMIN/DF) }\end{array}$ & $\leq 2,00$ & $\frac{0.98}{1.107}$ & Baik \\
\hline
\end{tabular}

\section{Hasil Pengujian Hipotesis}

Penelitianinimengujihubungan kausalitas dengan menggunakan uji dua sisi pada tingkat signifikansi sebesar 5\%. Hal ini sesuai dengan pernyataan Hair et al. (1998) bahwa penentuan nilai kritis tergantung pada penentuan teoretis mengenai hubungan yang diajukan. Jika hubungan positif atau negatif sudah dihipotesiskan, maka pengujian signifikansi satu arah dapat dilakukan. Pengaruh langsung (koefisien Jalur) diamati dari 
pengujian signifikansi dengan menggunakan nilai $\mathrm{CR}$, nilai $\mathrm{CR}$ yang direkomendasikan adalah $\geq \pm$ 2 dan probabilitasnya $\mathrm{p} £ 0,05$.

\section{Tabel 3. Hasil Pengujian Hipotesis}

\begin{tabular}{|c|c|c|}
\hline No & Hipotesis & Hasil \\
\hline 1 & $\begin{array}{l}\text { nilai orientasi manusia-alam } \\
\text { berpengaruh negatif terhadap sikap } \\
\text { menolak memakai pupuk organik } \\
\text { bersubsidi }\end{array}$ & $\begin{array}{l}\mathrm{p}: 0,131, \mathrm{CR}: \\
-1,509 \\
\text { hipotesis ditolak }\end{array}$ \\
\hline 2 & $\begin{array}{l}\text { pengalaman memakai pupuk organ- } \\
\text { ik bersubsidi berpengaruh negatif } \\
\text { terhadap sikap menolak memakai } \\
\text { pupuk organik bersubsidi }\end{array}$ & $\begin{array}{l}\text { p : } 0,006, \mathrm{CR}: \\
-2,758 \\
\text { hipotesis } \\
\text { diterima }\end{array}$ \\
\hline 3 & $\begin{array}{l}\text { norma subyektif berpengaruh } \\
\text { negatif terhadap minat menolak } \\
\text { memakai pupuk organik bersubsidi }\end{array}$ & $\begin{array}{l}\text { p : } 0,958, \text { CR : } \\
-0,053 \\
\text { hipotesis ditolak }\end{array}$ \\
\hline 4 & $\begin{array}{l}\text { harga berpengaruh positif terhadap } \\
\text { minat menolak memakai pupuk } \\
\text { organik bersubsidi }\end{array}$ & $\begin{array}{l}\text { p : } 0,493, \text { CR : } \\
0,686 \\
\text { hipotesis ditolak }\end{array}$ \\
\hline 5 & $\begin{array}{l}\text { harga berpengaruh positif terhadap } \\
\text { perilaku menolak memakai pupuk } \\
\text { organik bersubsidi }\end{array}$ & $\begin{array}{l}\text { p :0,516, CR : } \\
0,650 \\
\text { hipotesis ditolak }\end{array}$ \\
\hline 6 & $\begin{array}{l}\text { sikap menolak memakai pupuk } \\
\text { organik bersubsidi berpengaruh } \\
\text { positif terhadap minat menolak } \\
\text { memakai pupuk organik bersubsidi }\end{array}$ & $\begin{array}{l}\mathrm{p}: \\
3,672 \\
\text { hipotesis } \\
\text { diterima }\end{array}$ \\
\hline 7 & $\begin{array}{l}\text { minat menolak memakai pupuk } \\
\text { organik bersubsidi berpengaruh } \\
\text { positif terhadap perilaku peno- } \\
\text { lakan pemakaian pupuk organik } \\
\text { bersubsidi }\end{array}$ & $\begin{array}{l}\mathrm{p}: * * * *, \mathrm{CR}: \\
5,610 \\
\text { hipotesis } \\
\text { diterima }\end{array}$ \\
\hline
\end{tabular}

1. Hasil penelitian menunjukkan bahwa nilai kepedulian terhadap alam tidak berpengaruh pada sikap menolak pemakaian pupuk organik bersubsidi. Hal ini menunjukkan bahwa orientasi manusia alam petani baik yang menyatakan tidak peduli maupun yang menyatakan peduli ternyata tidak mempengaruhi sikap menolak memakai pupuk organik.

2. Hasil analisis data menunjukkan bahwa pengalaman masa lalu berpengaruh negatif terhadap penolakan pemakaian pupuk organik bersubsidi. Jika pengalaman masa lalu memuaskan dengan hasil panen yang tinggi menyebabkan sikap penolakan pemakaian pupuk organik menjadi rendah.

3. Hasil analisis data menunjukkan bahwa informasi tentang pupuk organik tidak berpengaruh pada minat menolak memakai pupuk organik bersubsidi. informasi dalam penelitian ini lebih banyak mengacu pada saran yang diberikan oleh orang lain untuk memakai pupuk organik bersubsidi ternyata tidak dapat mempengaruhi minat untuk memakai pupuk organik bersubsidi.

4. Hasil analisis data menunjukkan bahwa harga tidak berpengaruh positif pada minat menolak memakai pupuk organik bersubsidi. Harga pupuk organik bersubsidi tidak menjadi penyebab petani memiliki minat menolak memakai pupuk organik bersubsidi.

5. Hasil analisis data menunjukkan bahwa harga tidak berpengaruh positif pada perilaku penolakan pemakaian pupuk organik bersubsidi. Harga pupuk organik bersubsidi yang tinggi, persepsi resiko waktu, persepsi resiko psikologis, dan persepsi resiko fungsional tidak menyebabkan perilaku penolakan pemakaian pupuk organik bersubsidi.

6. Hasil analisis data menunjukkan bahwa sikap menolak memakai pupuk organik bersubsidi berpengaruh positif terhadap minat penolakan pemakaian pupuk organik bersubsidi.

7. Hal analisa data menunjukkan bahwa ketika petani cenderung mempunyai minat penolakan pemakain pupuk organik bersubsidi maka keputusannya untuk perilaku penolakan pemakaian pupuk organik bersubsidi juga tinggi.

\section{KESIMPULAN DAN SARAN}

\section{Kesimpulan}

Setelah dilakukan uji dan analisis permasalahan pada penelitian ini, maka dapat kesimpulan sebagai berikut :

1. Sikap menolak memakai pupuk organik bersubsidi tidak dipengaruhi oleh tinggi rendahnya kepedulian petani terhadap alam.

2. Pengalaman memakai pupuk organik bersubsidi hasil mempengaruhi sikap menolak memakai pupuk organik 
3. Informasi tentang pupuk organik tidak berpengaruh negatif terhadap minat petani dalam menolak memakai pupuk organik bersubsidi.

4. Harga tidak berpengaruh positif terhadap minat dan perilaku petani dalam menolak memakai pupuk organik bersubsidi.

5. Sikap menolak memakai pupuk organik bersubsidi mempunyai pengaruh positif dan signifikan terhadap minat menolak memakai pupuk organik bersubsidi.

6. Minat menolak memakai pupuk organik bersubsidi mempunyai pengaruh positif dan signifikan terhadap perilaku penolakan pemakaian pupuk organik bersubsidi.

7. Secara tidak langsung sikap menolak memakai pupuk organik bersubsdi juga berpengaruh terhadap perilaku menolak memakai pupuk organik bersubsidi. Hal ini terlihat dari nilai total efek sikap menolak terhadap perilaku menolak melalui minat menolak.

\section{Implikasi Penelitian}

1. Implikasi teori, faktor-faktor yang mempengaruhi penolakan pemakaian pupuk organik bersubsidi merupakan model perilaku yang baru karena memfokuskan pada perilaku menolak, sehingga hasil penelitian ini dapat digunakan untuk referensi dalam meneliti perilaku menolak dengan setting dan obyek penelitian lainnya.

2. Implikasi kebijakan pemerintah, adanya kecenderungan petani yang hanya berorientasi hasil dengan mengabaikan kelestarian alam sangat berbahaya untuk masa depan, oleh karena itu pemerintah perlu membuat kebijakan tentang penyuluhan tentang pentingnya menjaga kelestarian lama, penghargaan terhadap hasil pertanian organik, membuat demplot-demplot sebagai percontohan pertanian organik dan membuat forum antar petani supaya antar petani dapat saling bertukar pengalaman.

\section{Keterbatasan dan Saran Penelitian}

1. Penelitian ini mempunyai keterbatasan dari sisi setting penelitiannya, yaitu yang diamati adalah kelompok petani sayuran yang pernah memakai pupuk organik bersubsidi tetapi selanjutnya menolak memakai pupuk organik bersubsisdi.

2. Penelitian lanjutan tentang perilaku penolakan pemakaian pupuk organik bersubsidi perlu dilakukan dengan setting yang lain, latar belakang yang diteliti tidak hanya MNO dan pengalaman, tetapi kemungkinan bisa melibatkan latar belakang yang lain

3. Adanya pengaruh tidak langsung sikap menolak terhadap perilaku menolak memerlukan penelitian lanjutan dengan meneliti pengaruh sikap menolak terhadap perilaku menolak tanpa melalui minat menolak.

\section{DAFTAR PUSTAKA}

Ajzen, I (1985), "From Intentions to Actions: A Theory of Planned Behavior. In J. Kuhl and Beckman, J. (Eds.)," Action-control: From cognition to behavior (pp. 11- 39). Heidelberg, Germany: Springer.

(1988), Attitudes, Personality and Behavior. Milton Keynes: Open University Press.

(1991), "The Theory of Planned Behavior," Organizational Behavior and Human Decision Processes, Vol.50: 179-211

(2005), "Attitudes, personality, and behavior (2nd. Edition)," MiltonKeynes, England: Open University Press / McGraw- Hill.

Ajzen, I and Fishbein, M. (1975), Understanding attitudes and predicting social behavior. Englewood Cliffs, NJ: Prentice-Hall. (2000), "Attitudes and the AttitudeBehavior Relation: Reasoned and 
Automatic Processes. In W. Stroebe \& M. Hewstone (Eds.), European Review of Social Psychology (pp. 1-33). John Wiley \& Sons.

Aman, A.H.L., Harun.A and Husein, Z (2012), " The influence of Environmental Knowledge and Concern on Green Purchase Intention the Role of Attitude as a Mediating Variable", British Journal of Arts and Social Sciences, Vol 7, No II. Anderson, J.C and Gerbing, D.W (1988), "Structural Equation Modeling in Practice: A Review and Recommended Two-Step Approach," Psychological Bulletin, Vol. 103, No. 3, 411-423.

Arbuckle, J. L and Wothke, W (1996), Introduction to Structural Equation Modeling with Amos.American Statistical Association Continuing Education Course, Chicago.

Armitage, C.J and conner, M. (2001), "Effcacy of the Theory of Planned Behaviour, A meta-analytic review", British Journal of Social Psychology, 40, 471-499

Arsyad, I (2011), "Petani Menagih Janji SBY", Britanet, www.sinarharapan.go.id no 10.

Assael, H (1998), "Consumer Behavior and Marketing Action", Ohio: SouthWestern College Publishing.

Bagozzi, R. P (1981), "Attitudes, Intentions and Behavior: A Test of Some Key Hypotheses," Journal of Personality Social Psychology. Vol. 42, No. 4: 607627.

Baron, R.A and Byrne, D (2003), "Social Psychology $10^{\text {th }}$ ed. Boston: Allyn \& Bacon.

Baron, R.M and Kenney, DA."The ModeratorMediator Variable Distinction in Social Psychological Research: Conceptual, Strategic, and Statistical
Considerations," Journal of Personality and Social Psychology(51:6), 1986, pp. 1173-1182.

Baumgartner $\mathrm{H}$ and Homburg C (1996), "Application of Structural Equation Modeling in Marketing and Consumer Research: A Review", International Journal of Research in Marketing, Vol. 13 No.2, pp.139-61.

Bentler P.M (1983), "Some Contributions to Efficient Statistics in Structural Models: Specification and Estimation of Moment Structures", Psychometrika, 48, 493517

Bentler PM, Yuan K-H (1999), "Structural Equation Modeling With Small Samples: Test Statistics," Multivar. Behav. Res. 34:181-97

Bettman, J.R., M.F. Luce. And J. W. Payne (1998), "Constructive consumer Choice Processes", Journal of Consumer Research, Desember: 187-217.

Bisnis Manajemen (2013), "Pertanian Organik Raup Pendapatan Terbesar Tahun 2013”, 19 February.

Browne M.W and Cudeck R (1993), "Alternative Ways of Assessing Model Fit. in: Bollen, K. A. \& Long, J. S. (Eds.) Testing Structural Equation Models. pp. 136162. Beverly Hills, CA: Sage

BrownS.A and Venkatesh V (2005), "Model of Adoption of Technology in Households: A Baseline Model Test and Extension Incorporating Household Life Cycle," MIS Quarterly, 29(3):399-26

Chairy, J. (2012), "Perceived Risk, Moral Philosophy and Marketing Ethics: Mediating Influences on Sales Managers' Ethical Decision-making", Journal of Business Research, Vol. 55 No. 12, pp. 951-62. 
Chan, R. Y. K and Lau, L.B.Y (2000), "Antecedents of Green Purchases: A Survey in China," Journal of Consumer Marketing, Vol 17, No. 4. Pp 338-357.

Chi, T.T.N and Yamada. R (2002), "Factors Affecting Farmers' Aadoption of Technologies in Farming System: A case study in OMON district, Can Tho province, Mekong Delta", OmonRice journal, No. 10. Agricultural Publishing house, Ho Chi Minh city. P. 98-105.

Cooper, D.R and Schindler, P.S (2003), "Business Research Methods," $8^{\text {th }}$ ed. Boston: McGraw-Hill. Companies.

Cordano M, and Frieze I.H. (2000), "Pollution Reduction Preferences of U.S. Environmental Managers: Applying Ajzen's Theory of Planned Behaviour," Academy of Management Journal, 43 (4), pp. 627-641.

Daniel, M (2011), "Strategi Dan Kebijakan Pengembangan Pertanian Organik", http://www.harianhaluan.com, 13 April.

Danseh, S. Y. S., Hashemnia, S and Sefidmazgi, M. R (2012), "Evaluating Effective Factors on Customers' Attitude to by Green Products (Case study: consumers of products with A and Benergy labels in Rasht)," International Research Journal of Applied and Basic Sciences, 3(11), 2316-2322.

Davis F.D., Bagozzi R.P and Warshaw P.R (1989): "User Acceptance of Computer Technology,A Comparison of Two Theoretical Models."Management Science. (35). 982-1002.

Davis F.D (1989),"Perceived Usefulness, Perceived Ease of Use, and User Acceptance of Information Technology," MIS Quartely, 13. 319-339

Dharmmesta, B.S (1998), "Theory of Planned Behavior dalam Penelitian Sikap, Niat dan Perilaku Konsumen," KELOLA
Gadjah Mada University Business Review, Vol.7, No.18: 85-103.

Dholakia, R. R. (1999). “Going Shopping: Key Determinants of Shopping Behaviours and Motivations." International Journal of Retail and Distribution Management, 27(4): pp. 154-165.

Dholakia U. M (2001), “A Motivational Process Model of Produk Involvement and Consumer Risk Perception," European Journal of Marketing, Vol 35. No. 11/12, pp 1340-1360.

Dillman, D. A (1978), "Mail and Telephone Surveys: The Total Design Method", John Willy \& Sons, New York.

Engel J; Blackwell R and Miniard, P (1990), "Consumer Behaviour," $6^{\text {th }}$ ed. Sydney: Harcourt, Brace Jovanovich Publishers.

Engel, J.F., Blackwell, R.D and Miniard, P.W (1995), "Consumer Behavior", Chicago: The Dryden Press.

Feldman, M.L (1999), "Estimating the Value of Environmental Externalities for Foregone Generation on the North Fork of the Feather River", Report to Pacific Gas \& Electric Company, San Francisco, CA.

Ferdinand Augusty (2014) "Structural Equation Modeling” Seri Pustaka Kunci 13/2014 BP Undip.

Festinger, L. (1957). "A theory of cognitive dissonance", Evanston, IL: Row \& Peterson.

Fiore, Ann Marie and Kim, Jihyun (2007) "An integrative framework capturing experiential and utilitarian shopping experience", International Journal of Retail \& Distribution Management, Vol. 35 Iss: 6, pp.421 - 442

Fishbein, M And Ajzen, I (1975), Belief, Attitude, Intention, and Behavior: An Introduction to Theory and Research, MA: AddisonWesley Publishing Company, Inc 
Francis, K.S (1994), Consumer Satisfaction with Clothing Disposition", Journal of Consumer Satisfaction, Dissatisfaction and Complaining Behavior, Vol 7, pp: 184-190.

Gahtani A.S (2003), “Computer Technology Adoption in Saudi Arabia: Correlates of Perceived Innovation Attributes," Information Technology for Development. 10 (2003) 57-69 57

Hair Jr., Anderson R.E., Tatham R.L and Black W.C (1998), "Multivariate Data Analysis," New Jersey: Prentice-Hall International, Inc Hawkins D.I., Best.

Istiana, L., S.P., Syahlani, S.P and Nurtini,S (2008), "The Effect of Attitude, Subjective Norm and Behavioral Control on Intention and Buying Behavior of Ultra High Temperature Milk Product," Prosiding Semiloka Nasional Prospek Industri Sapi Perah Menuju Perdagangan Bebas-2020, April 21, UGM, Yogyakarta, Indonesia, pp: 507-512, (In Indonesian).

R.J and Coney K.A (2004), Consumer Behavior: Building Marketing Strategy. Boston: McGraw-Hill.

Havlena, W.J and Holbrook, M.B. (1986), "The varieties of consumption experience: Comparing two typologies of emotion in consumer behavior", Journal of Consumer Research, 13: 394-404.

Heat, C and Soll, J.B (1996), "Mental budgeting and consumer decision", Journal of Consumer Research, 23: 199-217.

Hogg, M and Vaughan, G (2005), "Social Psychology, $4^{\text {th }}$ ed. Essex, UK: Pearson Education Ltd.

Holbrook, M.B., \& Hirschman, E.C (1982), "The experiential aspects of consumption: Consumer Fantasies, Feelings and Fun", Journal of Consumer Research, 9: 132140.
Homer, P., and Kahle, L.R., Beatty S.E., (1998) "Alternative Measurement Approaches to Consumer values: The List of Values (LOV) and Values and Lifestyle (VALS)", Journal of Consumer Research, Vol 13 pp. 405-409

Hovav, A and Schuff, D (2005), "Global diffusion of the internet $\mathrm{V}$ : The changing dynamic of the internet-early and late adopters of the Ipv6 standard", Communication of the Association for Information System, 15: 242-262.

Jandt, F.E(2004), “AnIntroduction to Intercultural Communication: Identities in a Global Community," Sixth Edition.

Joseph, R.C (2005), “An Examination of Non Adoption and Decision Inertia A Web Based Perspective", Dissertation, The City University of NewYork.

Kim, H.S and Drolet, A (2003), "Choice and self expression: A cultural analysis of variety seeking", Journal of Personality and Social Psychology, 85.

Kim, S (2003), "Exploring Factors Influencing Personal Digital Assistant Adoption," Thesis of mass communication faculty, University of Florida.

Kivetz, Ran and Itamar Simonson (2000) The Effects of Incomplete Information on Consumer Choice. Journal of Marketing Research: November, Vol. 37, No. 4, pp. 427-448.

Klein, B and Janet E. Oglethorpe (1984) ,"Cognitive Reference Points in Consumer Decision Making", in NA - Advances in Consumer Research Volume 14, eds. Melanie Wallendorf and Paul Anderson, Provo, UT : Association for Consumer Research, Pages: 183-187

Klöckner, Christian A, (2011), “A comparative modelofthepsychologyofenvironmental behavior a-Meta- Analysis", Global 
Environmental Change, 23 (5), 10281038

Kotler, P (2004), "Marketing Management," New Jersey: Prentice Hall.

Kluckhohn, F. R and Strodtbeck, F. L (1961), "Variations in value orientations", Evanston, IL:Row, Peterson.

Kulikovski, V. and Agolli, M. (2011), "Drivers of Organic Food Consumption in Greece," International Hellenic University. pp 51 Lapointe, L and Rivard, S (2005), "A Multilevel Model of Resistance to Information Technology Implementation," MIS Quarterly, 29 (3): 461-491.

Limayem, M and Hirt, S. G (2003), "Force of Habit and Information Systems Usage: Theory and Initial Validation," Journal of the Association for Information Systems, Vol. 4: 65-97.

Lutz, R.J (1989), "Presidential Address Positivism, Naturalism and Pluralism in Consumer Research: Paradigms in Paradise," Advances in Consumer Research, Volume 16.

Mano, H. and Oliver, R.L (1993), "Assessing the Dimensionality and Structure of the Consumption Experience: Evaluation, Feeling and Satisfaction", Journal of Consumer Research, Vol. 20, December, pp. 451-66.

Marakas, G.M. and Hornik, S (1996) "Passive Resistance Misuse: Overt Support and Covert ecalcitrance in Is Implementation," European Journal of Information Systems, Vol. 5: 208-219.

Marcela, I (2010), “Adoption of Certified Organic Technologies: The Case of Coffee Farming in Columbia," Proceedings of the German Development Economics Conference, Hannover No. 58

Moenaart, R.K and Souder, W.E (1996), "Context and Antecedents of Information Utility at the R\&D Marketing interface," Management Science, Nov: 1592-1610.

Moons, I., De Pelsmacker, P., de Bont, C.J.P.M., Standaert A. (2010), "The Extended Decomposed Theory Of Planned Behaviour. A Framework for investigating The Adoption Process Of Electric Cars.The six senses: The essentials of Marketing," Conference Proceedings of the 39th EMAC Conference. Copenhagen.

Murnaghan, D., Blanchard, C., Rodgers, W., LaRosa, J., MacQuarrie, C., MacLellan, D., and Gray, B. (2009), "The Influence of Student Level Normative, Control, and Behavioral Beliefs on Staying Smoke-free: An Application of Ajzen's Theory of Planned Behavior", Addiction Research \& Theory. 17(5), 469-480.

Mowen, J. C and Mowen, M.M (1991), "Time and Outcome Valuation: Implications for Marketing Decision Making", Journal of Marketing, 55: 54-62.

Nikdavoodi, J (2012), “The Impact of Attitude, Subjective Norm, and Consumer Innovativeness, on Cosmetic Buying Behavior," Master Thesis In International Marketing And Brand Management, Department Of Business Administration. Lund University

Nunnally, J.C. 1978. Psychometric Theory. New York: McGraw Hill Book Company.

Ozanne, J.L., Brucks, M and Grewal, D (1992), "A Study of Information Search Behavior during the Categorization of New Products," Journal of Consumer Research, 18 (March), pp. 452-463.

Park, C. W., Mothersbaugh, D., and Feick, L (1994), "Consumer knowledge assessment," Journal of Consumer Research, Vol. 21: 71-82. 
Park, J., Yang, S and Lehto, X (2007), “Adoption of Mobile Technologies for Chinese Consumers", Journal of Electronic Commerce Research, Vol 8, N0.3.

Pavlou, P.A (2002), "Consumer Acceptance of Electronic Commerce: Integrating Trust and Risk with the Technology Acceptance Model," International Journal of Electronic Commerce, Spring, Vol. 7, No. 3, pp. 101-134.

Piderit, S.K (2000), "Rethinking Resistance and Recognizing Ambivalence: A Multidimensional View of Attitudes Toward an Organizational Change," Academy of Management Review, Vol. 25, No. 4, 783-794.

Ping, R.A (2004), “On Assuring Valid Measures for Theoretical Models Using Survey Data," Journal of Business Research, 57: pp. 125-141.

Petty, R.A and Cacioppo, J.T (1981), “Attitude and Persuasion: Classic and Contemporary Approaches," W.M.C. Brown Company Publisher, Dubuque, Lowa.

Purwanto,B.M.(2002), "The Effect of Salesperson Stress Factors on Job Performance," Jurnal Ekonomi dan Bisnis Indonesia, Vol.17: 150-169.

Purwoko,(2012) Studi Eksploratori di kawasan Pertanian Dieng

Ram, S (1987), "A Model of Innovation Resistance", Advances in Consumer Research, Vo. 14: 208-212.

Ram, S and Sheth, J.N (1989), "Consumer Resistance to Innovation: The Marketing Problem And Its Solutions," Journal of Consumer Marketing, 6 (Spring), pp. 5-14.

Rogers, E.M (1983), “Diffusion of Innovations,” $3^{\text {th }}$ ed. New York: The Free Press. (1995), "Diffusion of Innovations," $4^{\text {th }}$ ed. New York: The Free Press.
Schiffman, L.G. and L.L. Kanuk (2000), Consumer Behavior, $7^{\text {th }}$ Edition, New Jersey: Prentice Hall International, Inc (2010), "Consumer Behavior, $10^{\text {th }}$ Edition," New Jersey: Prentice Hall International, Inc.

Sheeran, P., Trafimow, D., and Armitage, C. J. (2003), "Predicting Behaviour from Perceived Behavioural Control: A Test of The Accuracy Assumption of the Theory of Planned Behaviour", The British Journal of Social Psychology, 42, 393-410

Sheppard, B.H; Hartwick, J and Warshaw, P.R (1988), "The Theory of Reasoned Action: A Meta-Analysis of Past Research With Recommendations for Modifications and Future Research," Journal of Consumer Research, Vol.15: 325-343.

Smith, J.R., Terry, D.J., Manstead, A.S., Louis, W.R., Kotterman, D. and Wolfs, J. (2008), "The Attitude-Behavior Relationship in Consumer Conduct, The Role of Norms, Past Behavior, and Selfidentity", Journal of Social Psychology, 148(3), 311-334.

Sridhar, S.S and Balachandran, B.V (1997), "Incomplete Information, Task Assignment, and Managerial Control Systems," Journal Management Science, Volume 43 Issue 6: 764-773.

Santrock, J. W. (2005), "Psikologi Remaja", PT Raja Grafindo Persada.

Stylianou, A.C and Jackson, P (2007), "A Comparative Exaniation of Individual Differences and Beliefs on Technology Usage: Gauging the Role of the IT Artifact," Journal of Computer Information Systems. Summer: 11-18. 
Tabachnick, B.G and Fidell, F.S (1996), Using Multivariate Statistic. $3^{\text {th }}$ Edition. New York: Harpoer Coolings Colledge Publisher.

Tanaka, J. S and Huba, G. J (1989), “A General Coefficient of Deterniation for Covariance Structure Models Under Arbitrary GLS Estimation,” British Journal of Mathematical and Statistical Psychology, Vol. 42: 233-239.

Taylor, S. and Todd, P (1995). "Decomposition and crossover effects in the theory of planned behavior: A study of consumer adoption intentions", International Journal of Research in Marketing, 12, 137-156

Tjahjono, H dan Ardi (2007), "Kajian Niat Mahasiswa Manajemen Universitas Muhammadiyah Yogyakarta untuk Menjadi Wirausaha," Utilitas, Jurnal Manajemen dan Bisnis, 16: 46-63.

Turley, L.W and LeBlanc, R.P (1993), "An Exploratory Investigation of Consumer Decision Making in the Services Sector", The Journal of Services Marketing, 7 (4) pp.11-18.

Venkatesh V and Davis F.D (1996), “A Model of The Antecedents of Perceived Ease of Use: Development and Test," Decision Sciences, Vol. 27:3. pp. 451-478

Venkatesh V dan Brown S.A (2001), "A Longitudinal Investigation of Personal Computers in Homes: Adoption Determinants and Emerging
Challenges," MIS Quarterly, Vol. 25 Issue 1, pp.71-102

Venkatesh V., Morris M.G., Davis G.B and Davis F.D (2003), "User Acceptance of Information Technology: Toward A Unified View," MIS Quarterly, 27:3. pp: 425-478.

Wang, Ming-Shen; Chen, Chih-Chung; Chang, Su-Chao; Yang, Yung-Her (2007), "Effects of Online Shopping Attitudes, Subjective Norms and Control Beliefs on Online Shopping Intentions: A Test of the Theory of Planned Behaviour," International Journal of Management, Vol. 24, No. 2.

Wijaya, T (2013), "Model Perilaku Beli Makanan Organik", Disertasi Universitas Islam Indonesia, Tidak dipublikasikan.

Yuwono, T. (2008), "Bioteknologi Pertanian", Gadjah Mada University Press: Yogyakarta.

Batur dalam Angka, 2012.

Balai Penelitian Tanah, Kementrian Pertanian Republik Indonesia 2013.

Peraturan Menteri Pertanian, Nomor 70/ Permentan/SR.140/10/2011 Tentang Pupuk Organik, Pupuk Hayati Dan Pembenah Tanah.

Suara Merdeka, 30 Agustus 2005.

Suara Merdeka, 19 Juni 2006. 